\title{
Traffic Safety on the Roads of Republika Srpska
}

\author{
Dušan Janković*, Stojan Aleksić \\ Faculty of Traffic Engineering, International University of District Brcko Bosnia and Herzegovina, Bosnia and Herzegovina
}

Copyright $\mathrm{C} 2018$ by authors, all rights reserved. Authors agree that this article remains permanently open access under the terms of the Creative Commons Attribution License 4.0 International License

\begin{abstract}
The monitoring and analysis of traffic safety is an important part of a process in the area of traffic safety control. In a relatively long period of time, based on the analysis in a real time frame, there can be seen some changes of parameters in traffic safety which gives us the insight in the success of so far activities and the prediction of future traffic accidents can be done. Based on the most recent experience and best practices, it is desirable to analyze as many cases as we can in order to understand and interpret the tendencies in traffic safety correctly. However, this requires the constant monitoring of cases, examination of general tendencies and their analyses. This paper analyses the indicators of traffic safety (the number of traffic accidents with casualties, the number of killed and injured) from 2012 to 2017 on the roads of Republika Srpska entity. Special attention, beside traffic accidents, is given to regulations, the costs of traffic accidents and to the performance audit.
\end{abstract}

Keywords Traffic Accidents, Causes, Cases, Regulations, Costs

\section{Introduction}

Every year in the world, especially in underdeveloped and developing countries, 1.3 million people die in traffic accidents, and over 50 million people suffer minor or severe injuries. Therefore, traffic road deaths are the leading cause of premature deaths in the world [11].

The research done by the EuroRAP characterized the roads of Bosnia and Herzegovina as the least safe, and more than half traffic roads are said to be high-risk roads where traffic accidents with fatal outcomes happen two to three times more than on the roads of Europa [4]. From 2012 to 2017, there were 223997 traffic accidents in Bosnia and Herzegovina $(\mathrm{BIH})$ in which 1952 people lost their lives and 61119 people suffered some injuries.

The media in the Republika Srpska entity (RS) almost every day are reporting about traffic accidents, their causes and consequences, and places on which the accidents are the most frequent. Beside the number of injured people, the material damages as a result of traffic accidents are in the focus of public.

Traffic accidents are recognized over the world as a global, health, social and economic problem. The United Nation (UN), the World Health Organization, the Global Alliance of NGOs for Road Safety, the World Bank and many other important organizations prepared many documents (resolutions, directives, plans, strategies and recommendations) aiming at reducing the death rate in traffic accidents on the world's roads, especially in the developing countries.

The Republika Srpska entity, together with other members of UN, accepted a series of resolutions about traffic safety of the United Nation General Assembly, among which the most important is Resolution 64/225, adopted in May 2010. This resolution is determined by the UN document 'The Decade of Action for Road Safety 2011-2020'.

'The Road safety strategy 2013-2022' was adopted in May $19^{\text {th }} 2013$ by The National Assembly of Republika Srpska. Both the strategy and action plan are designed to be in line with the new recommendations of the United Nation General Assembly and with the recommendations of the World Health Organization for developing countries and with the highest international practice.

Both documents are aiming at multiple efforts (within the relevant private and public sectors in Republic of Srpska) of reducing the rate of dead and injured people on the roads of Republic of Srpska entity. All activities are centered around the most important risk factors: alcohol, speeding, seat belt legislation, creating a safe environment for pedestrians, traffic education in schools, increasing public awareness on risks, improving safety of vehicles and the environment, and also proper post-crash care.

If all activities, defined by the strategy, are to be implemented consistently, 586 human lives can be saved, 7033 people can be saved from severe injuries, 41082 people can be saved from minor injuries, and the amount of 582 million BAM for economic costs can be saved [10]. 
Table 1. Traffic accidents and casualties in RS (from 2012 to 2017)

\begin{tabular}{|c|c|c|c|c|c|c|c|}
\hline \multirow{2}{*}{$\begin{array}{c}\text { THE STRUCTURE OF TRAFFIC ACCIDENTS } \\
\text { AND CASUALTIES }\end{array}$} & \multicolumn{6}{|c|}{ YEAR } & \multirow{2}{*}{$\Sigma$} \\
\hline & 2012 & 2013 & 2014 & 2015 & 2016 & 2017 & \\
\hline THE NUMBER OF TRAFFIC ACCIDENTS & 9378 & 8441 & 8588 & 8581 & 9.295 & 9783 & 54066 \\
\hline - with killed persons & 150 & 130 & 146 & 123 & 135 & 121 & 805 \\
\hline - with severe injuries & 577 & 538 & 495 & 534 & 604 & 575 & 3323 \\
\hline - with minor injuries & 1526 & 1314 & 1472 & 1505 & 1660 & 1723 & 9200 \\
\hline - with material damages & 7125 & 6459 & 6475 & 6419 & 6896 & 7364 & 40738 \\
\hline PERSONS KILLED OR INJURED/CASUALTIES & 3382 & 2960 & 3089 & 3155 & 3644 & 3711 & 19941 \\
\hline - killed & 163 & 140 & 153 & 131 & 150 & 130 & 867 \\
\hline - seriously injured persons & 702 & 651 & 602 & 632 & 752 & 703 & 4042 \\
\hline - slightly injured person & 2517 & 2169 & 2334 & 2392 & 2742 & 2878 & 15052 \\
\hline
\end{tabular}

\section{Traffic Accidents on the Roads of the Republika Srpska Entity}

By observing traffic accidents over a longer period of time, the dynamics of their occurrence can be confirmed, and the number of accidents during a certain period of time in the observed area. Based on those indicators, the prediction of their occurrences for the next period can be made.

According to the reports of the Ministry of Interior of Republika Srpska, from 2012 to 2017, there were 54066 traffic accidents in the Republika Srpska entity in which 867 people lost their lives, 4042 people had severe injuries and 15032 people had slight injuries (Table 1). And when it comes to the economic losses, the Republika Srpska entity lost more than 1 billion and 44 million BAM (more than 55 million $€$ ). There is no economy in the world that could endure such big losses every year [3].

When it comes to the number of traffic accidents in the Republika Srpska entity, it can be said that their number has not decreased yet, but that there is an oscillating trend in the total number of traffic accidents. This is the characteristic of countries that do not have stable and strong traffic safety systems. Therefore, it is of a high importance to improve the capacity and integrity of a person or institution who/which carries out measures and activities for reducing traffic injuries and deaths.

If one wants positive results in reducing the number and severity of traffic accidents, it is necessary to continuously monitor the state of security in a particular area and promptly response to changes happening in traffic.

A qualitative analysis aims to show causative factors and to determine the degree of impact of each of them on traffic. In this research, the characteristics of the causes and factors by elements are usually emphasized in the first place. The science which studies the causes of traffic accidents is called etiology.

Improper speed, regardless of road conditions or of speed limit, is without any doubt, one of the main cases of traffic accidents in the Republika Srpska entity (around $30.78 \%$ ). After them, there are traffic accidents caused by some actions of vehicle in traffic, violation of right-of-way, tailgating, and some other cases stated as the causes of traffic accidents in the reports of Ministry Interior of RS (Table 2).

In practice and in literature too, the causes and manifestations often do not differ (etiology and phenomenology). However, the cause of a traffic accident is what directly affected the inner behavior of driver to make a manifestation like improper overtaking, improper speed, etc. In the reports of Ministry interior, it is stated that the cause of an accident is improper speed or overtaking or violation of right-of-way, etc. This misinterpretation of causes and manifestations hinders the identification of real causes of traffic accidents and creates misconception, because manifestations are said to be causes. In that way, measures of social intervention are directed towards prevention of manifestations instead of suppression of the real causes of accidents. Therefore, it is necessary to try to more fully differentiate between the manifestations and causes of traffic accidents in the context of statistical monitoring, and that people who engage in any form of statistical procedure (recorded, analyzed or concluded) understand the difference between manifestations and causes of traffic accidents. In that way, and by eliminating some other deficiencies in the way of data collection (unevenness of criteria, estimation and defining), one would come to a more useful and beneficial statistics which would give a more realistic picture of the actual state than the existing one. 
Table 2. The causes of traffic accidents stated in the reports of the Ministry of Interior of Republika Srpska (from 2012 to 2017)

\begin{tabular}{|c|c|c|c|c|c|c|c|c|c|}
\hline & \multirow{2}{*}{ CAUSE } & \multicolumn{6}{|c|}{ THE NUMBER OF TRAFFIC ACCIDENTS } & \multirow[b]{2}{*}{$\Sigma$} & \multirow[b]{2}{*}{$\%$} \\
\hline & & 2012 & 2013 & 2014 & 2015 & 2016 & 2017 & & \\
\hline 1. & Actions with vehicle in traffic & 2773 & 2486 & 2339 & 2015 & 2613 & 2479 & 14705 & 27.24 \\
\hline 2. & Improper speed & 2675 & 2747 & 2761 & 2735 & 2789 & 2935 & 16642 & 30.78 \\
\hline 3. & Violation of the right-of-way & 1132 & 1004 & 1087 & 1032 & 1156 & 1293 & 6704 & 12.39 \\
\hline 4. & Tailgating & 1041 & 922 & 1016 & 998 & 1056 & 1343 & 6376 & 11.79 \\
\hline 5. & Wrong-way driving & & & & 768 & 206 & 451 & 1425 & 2.63 \\
\hline 6. & $\begin{array}{l}\text { Improper moving by a vehicle from } \\
\text { opposite directions }\end{array}$ & 522 & 364 & 358 & 259 & 307 & 267 & 2077 & 3.84 \\
\hline 7. & Improper overtaking & 285 & 219 & 215 & 212 & 246 & 259 & 1436 & 2.65 \\
\hline 8. & Pedestrians faults & 53 & 52 & 48 & 47 & 53 & 47 & 300 & 0.55 \\
\hline 9. & $\begin{array}{l}\text { Improper passing of a non-moving } \\
\text { vehicle }\end{array}$ & 52 & 35 & 41 & 52 & 57 & 63 & 300 & 0.55 \\
\hline 10. & Road factor & 26 & 24 & 24 & 24 & 26 & 22 & 146 & 0.28 \\
\hline 11. & $\begin{array}{l}\text { Technical malfunction of the } \\
\text { vehicle }\end{array}$ & 16 & 14 & 15 & 15 & 16 & 22 & 98 & 0.18 \\
\hline 12. & Motorcyclists faults & & 13 & 6 & 5 & 5 & 5 & 34 & 0.06 \\
\hline 13. & Bicyclist faults & 16 & 10 & 14 & 9 & 14 & 13 & 76 & 0.14 \\
\hline 14. & Moped drivers faults & & 13 & 5 & 5 & 7 & 1 & 31 & 0.06 \\
\hline 15. & Other causes & 787 & 538 & 659 & 405 & 744 & 583 & 3716 & 6.86 \\
\hline & $\Sigma$ & 9378 & 8441 & 8588 & 8581 & 9295 & 9783 & 54066 & 100 \\
\hline
\end{tabular}

For successful prevention of traffic accidents, it is necessary to determine first the causes of their occurrences, and then design an effective reaction of the society. It is a rare case that traffic accidents happen for just one cause. They are usually a result of one complex, intertwined, simultaneous effect of a number of different objective and subjective factors: causes, conditions, reasons, states, circumstances, elements, habits, attitudes, beliefs, social and biological motives and numerous other factors. These factors are not limited only to human actions and behavior, but also to some objective factors. When it comes to objective factors, various social, technical and natural factors are most commonly intertwined with each other at the same time. However, based on previous research, it can be said with certainty that the role of human factor is most important [7]. The subjective factor (man) is attributed to $80-95 \%$ of all traffic accidents, while the remaining $5-20 \%$ is an objective factor (vehicle and road).

According to the data in Table 2, in the structure of the causes of traffic accidents on Republika Srpska's roads, $99.54 \%$ of traffic accidents are assigned to the subjective factor (man). However, that doesn't mean that the human mistake is always the only cause of a traffic accident. Although mistakes of subjective nature have been dominant, a large percentage of accidents is often attributed to man because the society transfers some of its guilt to an individual by requiring them to adjust their behavior to conditions that are not optimal, and to compensate for the deficiencies with increased attention. In addition, a subjective mistake often comes as a consequence of objective circumstances (road and vehicle) such as, for example, feeling tired faster than usual due to a bad road or uncomfortable vehicle, etc.

In the structure of the causes of traffic accidents on the Republika Srpska's roads, technical factors (road and vehicle) have the percentage of 0.46 (Table 2). This small percentage of objective (technical) factors in the statistics is a consequence of the habit Ministry of Interior (hereinafter, MUP RS) to cite only one cause (factor) in the statistical report, and ignore many other factors that, observing together, are of the high importance. In addition, the members of MUP RS are not fond of entering objective factors, because then there won't be any court process (there is no subjective responsibilities), where the truth can be better established by the presentation of various pieces of evidence, and they can be accused for being subjective. The main reason for small percentage of objective factors (road and vehicle) is that it is difficult to determine on the 
spot the structure, interaction, causal relationships, and the legitimacy of many factors.

According to the statistic data of MUP RS, the effect of technical factors (road and vehicle) on the occurrence of traffic accidents is ignored. In the period from 2012 to 2017 , the road as a main cause of traffic accidents is mentioned in $0.28 \%$ of accidents (Table 2). Having in mind the whole road network, the road must have been the main cause more often than registered.

In the same way, the vehicle as a main cause of traffic accidents was mentioned in $0.18 \%$ of accidents what is unacceptable having in mind that the age structure of vehicles wasn't very promising. On the other hand, the technical safety of vehicle was endangered by other factors such as problems with spare parts, motor fuel, etc. If we also take into account that bad roads contribute to faster destroying of vehicle's technical safety, it is clear that the effect of vehicle is ignored as a cause of traffic accidents on roads of Republika Srpska.

Traffic accidents are one complex phenomenon and it cannot be simplified to just simple formulas and mechanisms such as man, road, vehicle. They are the result of extensive and intertwined combinations of various factors. Some crucial, first-hand factors would have stayed without a concrete realization if there hadn't been other causes, circumstances and elements. Without an exact methodology and deeper studying of real causes and mechanisms of accidents' occurrences, it is not possible to determine for sure which factor, and in what measure, contributes to the occurrence of traffic accidents.

\section{Legal Regulations and Levels of Responsibilities in the System}

The field of traffic safety on the roads of Republika Srpska is regulated by the Law of Traffic Safety on roads in $\mathrm{BiH}$ and by the Law of Traffic Safety on roads of Republika Srpska. However, for this very field there are some other important laws, strategic documents, and some bylaws in the form of decisions, regulations, programs, instructions, guidelines, etc.

Traffic safety on the roads of Republika Srpska represents a complex system, with numerous elements, authorities and responsibilities. According to the Law of traffic safety on roads of Republika Srpska, the administrative authority and institutions responsible for the traffic safety state are the Ministry of Transport and Communication, the Ministry of Interior, the Ministry of Education and Culture, the Ministry of health and Social care, the Agency, the Republic Administration for Inspection activities, the Auto-moto association of Republika Srpska, public companies entrusted with management of the road network and local self-government units.

Responsibilities and obligations of institutions according to the Law of Traffic Safety on roads of Republika Srpska and other relevant regulations are:

- The Government of Republika Srpska directly, or through Road safety council and line ministries, supervises the work of the republic institutions in the system of traffic safety, considers issues, suggests measures for improving traffic safety, and initiates the creation and adoption of laws and other acts.

- Traffic police, or authorized persons, directly monitor the state of traffic on roads, check persons and vehicles in the sense of respecting laws and regulations adopted on the basis of the law. They also make preventive and repressive control over the traffic and within it they educate and warn drivers. They apply protective measures and issue misdemeanor warrants. They also register, investigate and punish all irregular behaviors in traffic.

- $\quad$ Road managers have responsibility to secure that all public roads intended for traffic are constructed in accordance with traffic safety requirements. Public roads must be maintained so as to meet traffic safety requirements. New roads must pass the system of revision, and the old ones the system of safety checking. Road managers are obliged to organize permanent control of road condition and the maintenance of public roads, objects, traffic signs and other equipment on roads for the safe and undisturbed traffic. They are obliged to check the state of traffic safety on roads, to make analysis of dangerous places on the road and take measures to eliminate them.

- Local authorities control the condition and maintenance of roads they cover, objects, traffic signs and equipment on the roads in a way that the traffic is safe and undisturbed. They are responsible for removing all the problems on roads which can provoke a traffic accident, and all other tasks determined by the law. They are obliged to form local councils for traffic safety, and to make strategic plans and programs of traffic safety.

\section{Costs of Traffic Accidents in Republika Srpska}

Road traffic safety is a problem in the whole world and numerous countries try to reduce the number of dead and injured persons on their roads. When coming to that issue, the first step is to examine the actual and potential losses which are the result of traffic accidents.

The socioeconomic losses resulting as a consequence of traffic accidents on Republika Srpska roads are calculated by the gross Output Method (Human capital approach-Ex post approach)-a methodological approach used in many 
countries [3]. By applying this method the following costs are estimated: costs of administration, proper care of injured, damage on property, lost productivity of dead and injured, as well as compensation for physical pain, mental pain and trauma. The most important results of this research are shown below.

Individual costs components in each category of traffic accidents and casualties are shown in Table 3. If rough estimation of physical pain, mental pain and trauma is calculated in this calculation, human costs are 520950 BAM for each person killed in traffic accidents, 20776 BAM for each severely injured person, and 693 BAM for each person with minor injuries. Even in the cases where physical pain, mental pain and trauma are excluded, the cost for each person killed in traffic accidents will be 372000 BAM.

Table 3. Losses for every casualty of traffic accident according to the degree of severity in Republika Srspka

\begin{tabular}{|l|r|r|}
\hline \multirow{2}{*}{ CONSEQUENCES } & \multicolumn{2}{|c|}{ COSTS } \\
\cline { 2 - 3 } & \multicolumn{1}{|c|}{ BAM } & \multicolumn{1}{c|}{ EUROS } \\
\hline Killed & 520950 & 266358 \\
\hline Seriously injured & 20776 & 10621 \\
\hline Slightly injured & 693 & 354 \\
\hline
\end{tabular}

In the most of cases, more than one casualty is involved, so when calculating the costs on the basis of one traffic accident, the number of casualties according to the consequence of the accident must be determined. Table 4 shows the average number (rate) of casualties for each class of accident based on the estimated number of casualties and estimated number of traffic accidents. Having in mind that in the traffic accidents resulting with injuries there are more than one casualty, the estimated cost is 620618 BAM per accident with killed persons, 66683 BAM per accident with severely injured persons, and 6221 BAM per accident with slightly injured persons, while in traffic accidents resulting just in material damage on property the cost is 3258BAM.

It should be noted that the values of economic losses shown above are the minimum ones. If the approach 'willingness to pay' is used in this process, the values would be two or three times higher. However, the mentioned approach requires an extensive examination of opinions, and its implementation would be very expensive, long-term and complicated. For those reasons, many countries use the 'human capital' approach (the same is done in Republika Srpska), knowing that the calculation has absolutely minimal value, and that if these findings can justify intervention, then they would be even more justified by using any other method of calculating costs.

Table 4. Losses per each traffic accident according to the degree of severity in Republika Srpska

\begin{tabular}{|c|c|c|}
\hline \multirow{2}{*}{$\begin{array}{c}\text { THE DEGREE OF SEVERITY OF TRAFFIC } \\
\text { ACCIDENT }\end{array}$} & \multicolumn{2}{|c|}{ COSTS } \\
\hline & BAM & EUROS \\
\hline Accidents with killed persons & 620618 & 317317 \\
\hline Accidents with severely injured persons & 66683 & 34094 \\
\hline Accidents with slightly injured persons & 6221 & 3181 \\
\hline Accidents with only material damages on property & 3258 & 1666 \\
\hline
\end{tabular}

\section{Performance Audit}

In 2013, the Supreme Office for Public Sector Auditing in Republika Srpska carried out a performance audit called 'Traffic safety on Republika Srpska's roads'. The aim of this audit was to investigate and estimate whether the responsible institutions effectively work on the prevention of traffic accidents, on reducing the number of dead and injured persons, and whether the expected results are achieved.

The audit came to the following results:

Traffic police controls in the observed period of time didn't reduce the leading causes of traffic accidents.

The current way of checking speed and driving under the influence of alcohol is not efficient; the expected results are not achieved.

Planning of traffic police controls is done without any objective criteria and without an overall tracking of some indicators which would help to determine priorities and expected results.

Traffic police in the observed period of time didn't modernize the controls, and the existing resources were not equally located between traffic safety stations. 
Neither a functional system of data exchange among institutions in traffic safety system has been established yet, nor the data base on all important traffic safety indicators have been established fully.

Road managers in Republika Srpska didn't identify, mark or remove dangerous places on the roads in the observed period of time.

A clearly defined way of controlling, analyzing of adequacy and matching the existing speed limits on roads wasn't established.

Most of the roads in Republika Srpska have neither projects of traffic signalization nor elaborates on planned speed.

Road managers rarely used some traffic calming measures, and even less often those measures were applied on the basis of traffic accidents indicators.

The findings of the audit indicate the existence of a significant space for improving the safety of traffic on the roads of the Republika Srpska, and therefore for reducing the number of people killed and seriously injured in traffic accidents, as well as for reducing the social costs of the consequences of traffic accidents.

\section{Conclusions}

In comparison with other countries in the region, especially with developed ones, traffic road network in Republika Srpska is relatively inefficient and unsafe. When we talk about international standards, the rate of traffic accidents, especially those with fatal consequences, is unacceptably high.

The growing problem of traffic accidents and human victims has made traffic safety as one of the most important state problem, and thus it became a component of road projects in Repubika Srpska, which are financed by World Bank loans.

Republika Srpska is still in an early phase of developing traffic safety on its roads, and the basic possibilities, activities and resources are still not available to the key entities or to the existing system in Republika Srpska. Before the key system and knowledge are set to its place, a lot of effort will be required to enforce capacity, practice and activities important for establishing an efficient work in the field of traffic safety.

Some important steps have been taken in the last six years in Republika Srpska on establishing the system of traffic safety management. The Law of Traffic Safety on the roads of Republika Srpska was adopted, the World Bank project 'Improvement Of Road Safety Management And Conditions In the Republika Srpska' was fulfilled, a new Traffic Safety Council and the Traffic Safety Agency were formed.

Within the project 'Improvement Of Road Safety Management And Conditions In the Republika Srpska', in the presence of all representatives of traffic safety system and with the technical support of consulting team, all sectors of traffic safety were analyzed and on the basis of that, The Strategy and Program of traffic safety for Republika Srpska were adopted. Within this project, The Economics Institute from Banja Luka made a research on losses which the economy of Republika Srpska endures due to traffic accidents. From the reports on cost of traffic accidents in Republika Srpska, it can be seen that those costs are very high, even when a conservative estimation method was used. The values would be two or three times higher if the estimation method was 'willingness-to pay'.

Taking into account those annual losses, the authorities should invest more in exploring the traffic safety on the roads, in order to better understand the causes of traffic accidents. Investing in road safety should be considered as an 'investment' rather than 'cost'.

All activities would give a positive result and reduce the number of casualties on the roads of Republika Srpska if there is a support for implementation of Traffic Safety Program, not just political one, but also financial and professional support, and also the readiness of all traffic safety entities to work together to implement measures of traffic safety.

The experience of highly developed countries, especially European ones, shows that the number of traffic accidents and the killed persons can be reduced through strategically designed and systemic efforts within the key sectors, with good political and financial support. This can be used in the realization of strategy and program of traffic safety. Having in mind that this is a global problem, which many countries faced with and learnt very expensive lessons, the authorities of Republika Srpska should learn from their experience. Namely, there are some rich experiences and proved solutions which can be used for improving the traffic safety on roads. Efficient solutions are well-known and available for solving this global problem. It only takes resources and readiness to apply them, and also there should be clearly clarified responsibilities for effective activities in order to achieve success.

\section{REFERENCES}

[1] Road Traffic Safety Action Plan in RS (2013-2022), Banja Luka, 2013. Paper Format of the Journal of Traffic and Transportation Engineering

[2] BIHAMK, Report on Number of Traffic Accidents from 2011-2017. Sarajevo, 2018.

[3] Economic Institute Banja Luka, Transport Accident Costs in RS, Banja Luka 2012.

[4] EuroRAP, European Road Safety Atlas, European Road Assessment Program, 2011.

[5] Final Report on Improvement of Road Safety Management 
and Conditions in Republic of Srpska (SweRoad, Jun 2012).

[6] The Main Public Sector Audit Service of Republic of Srpska, Performance Report on Traffic Safety on Roads in the RS, No.: RU004-12, Banja Luka, 2013.

[7] Inić, M., Safety of Road Traffic, Faculty of Technical Sciences in Novi Sad, Novi Sad, 1991.

[8] MUP RS, Information on Traffic Safety in RS from 2011-2017. Banja Luka, 2018.

[9] Guidelines for Road Design, Construction, Maintenance and Supervision, Part 1, "Road Design", Chapter 5: "Traffic Signaling and Equipment", Sarajevo / Banja Luka, 2005.

[10] Traffic Safety Strategy on Roads in RS (2013-2022), Banja Luka, 2013
[11] WHO (World Health Organization), Global Plan for the Decade of Action for Road Safety 2011-2020 Geneva, Switzerland, 2011.

[12] ZOOBS BiH, Law on Basic Safety of Road Traffic in Bosnia and Herzegovina - The Official Gazette of $\mathrm{BiH}$ br. 6/06 - 417; 75 / 06-6580; 44 / 07-5270; 84 / 09-014; 48 / 1010; and 8/17, Sarajevo, 2006.

[13] ZOBS RS, Law on Road Traffic Safety of Republic of Srpska - Sl. glasnik RS št. 63 / 11-1, Banja Luka, 2011.

[14] ZOJP RS, Law on Public Roads of Republic of Srpska. - Fig. The Official Gazzete of Republic of Srpska br. 89/13, Banja Luka 2013. 